\title{
DETEKSI PERUBAHAN PENGGUNAAN LAHAN DENGAN CITRA LANDSAT DAN SISTEM INFORMASI GEOGRAFIS: STUDI KASUS DI WILAYAH METROPOLITAN BANDUNG, INDONESIA
}

\author{
N. Wijaya ${ }^{\text {a }}$ \\ a Institut Teknologi Bandung, Indonesia
}

Article Info:

Received: 6 July 2015

in revised form: 5 September 2015

Accepted: 5 Oktober 2015

Available Online: 31 October 2015

\section{Keywords:}

Bandung, landuse changes detection, GIS, landsat imagery, urban area

\section{Corresponding Author:} Nurrohman Wijaya Institut Teknologi Bandung, Bandung, Indonesia Email: nuroc 2000@yahoo.com

\section{Info Artikel:}

Diterima: 6 Juli 2015

Hasil Revisi: 5 September 2015

Disetujui: 5 Oktober 2015

Publikasi On-Line: 31 Oktober 2015

\section{Kata Kunci:}

Bandung, deteksi perubahan penggunaan lahan, SIG, citra landsat, daerah perkotaan

Kontak Penulis: Nurrohman Wijaya Institut Teknologi Bandung, Bandung, Indonesia Email: nuroc2000@yahoo.com
Abstract: Land use change becomes one of the significant issues for planners and decision makers in urban and regional policy. Data, information, and tool sometimes turn to be a burden in the process of detection of land use change. It is expected that increasing of accessibility presently will be straightforward to conduct the land use change detection. This study aims to demonstrate the land use detection with data and tool that are available. Landsat images and Geographical Information System (GIS) analysis are used to detect land use change in the urban area of Bandung Metropolitan Area (BMA) in Indonesia in three periods, which are 1979, 2006, and 2014. Land use change of BMA is identified through satellite images of Landsat MSS 1979, Landsat TM 2006, and Landsat OLI 2014, and the use of GIS for analyzing the land use classification. Based on the results, expansion of urban area has been increasing. Development of settlement area is more growing, and forest land is significantly declining. The interesting result is the increasing of industrial and commercial areas. It indicates that most land use is changing from non-built up area to built up one, and urban area is sprawling to the surroundings. It gives a challenge for urban area development of BMA. Planners and policy makers take part in an important role to keep the urban area developing in a sustainability way.

Abstrak: Perubahan penggunaan lahan menjadi salah satu isu penting bagi para perencana dan penyusun kebijakan perkotaan dan wilayah. Data, informasi dan alat analisis kadangkala menjadi kendala dalam mendeteksi perubahan guna lahan. Semakin meningkatnya akses data dan teknologi, maka saat ini diharapkan pendeteksian guna lahan dapat dilakukan dengan sederhana. Oleh karena itu, penelitian ini bertujuan untuk melakukan demonstrasi terhadap pendeteksian perubahan guna lahan dengan menggunakan data dan alat analisis yang mudah diakses. Citra Landsat dan analisis Sistem Informasi Geografis (SIG) digunakan untuk mendeteksi perubahan guna lahan di Wilayah Metropolitan Bandung (WMB), Indonesia pada tiga kurun waktu yaitu tahun 1979, 2006, dan 2014. Perubahan guna lahan perkotaan di WMB teridentifikasi melalui data citra satelit Landsat MSS 1979, Landsat TM 2006, dan Landsat OLI 2014, serta penggunaan SIG dalam menganalisis klasifikasi guna lahan. Berdasarkan hasil yang diperoleh, ekspansi daerah perkotaan telah terjadi peningkatan. Pemanfaatan lahan permukiman semakin meningkat, sedangkan peruntukan lahan hutan semakin berkurang. Hal menarik adalah adanya peningkatan peruntukan lahan industri dan komersial. Ini mengindikasikan bahwa telah terjadi perubahan alih fungsi lahan dari yang tidak terbangun menjadi lahan terbangun, serta pemekaran daerah perkotaan ke daerah sekitarnya. Ini memberikan tantangan yang cukup signifikan bagi pengembangan daerah perkotaan WMB. Para perencana dan pembuat kebijakan memiliki peran penting dalam usaha mempertahankan daerah perkotaan tetap berkembang secara berkelanjutan. 


\section{PENDAHULUAN}

Perubahan penggunaan lahan atau tutupan lahan merupakan hal yang umum terjadi, baik dalam bidang pengembangan kota dan wilayah, serta pengelolaan sumber daya alam. Perubahan lahan menjadi salah satu isu penting bagi para perencana dan penyusun kebijakan, khususnya di negara-negara berkembang, dimana masalah penegakan hukum dan kebijakan pengelolaan antar institusi baik horisontal dan vertikal masih lemah. Salah satu dampak dari akibat perubahan guna lahan yang tidak teratur adalah berkurangnya fungsi produktivitas biologis dan keberagaman kehidupan ekosistem yang terdapat di lahan tersebut. Secara umum, praktik perubahan guna lahan dan tutupan lahan dapat diartikan sebagai konversi lahan menjadi lahan perkebunan dan peternakan, perluasan fungsi lahan pertanian, penggundulan hutan, penanaman kembali fungsi lahan hutan, penggantian tanaman, dan perluasan lahan perkotaan (urban sprawl). Oleh karena itu, konsep pengelolaan secara berkelanjutan terhadap sumber daya alam perlu diperhatikan dalam upaya penyediaan barang dan jasa ekologis yang dapat digunakan untuk kebutuhan generasi saat ini dan juga untuk masa mendatang dengan cara mengenali dan mengadaptasi ketergantungan dan keterbatasan kondisi biofisik yang dapat diperbarui atau tergantikan (Evrendilek dan Doygun, 2000). Berdasarkan hal tersebut, isu terkait perubahan guna lahan masih relevan untuk dilakukan kajian studi dalam konteks aplikasi pendeteksian perubahan guna lahan.

Beberapa kajian studi telah dilakukan sebelumnya oleh para peneliti terkait dengan perubahan guna lahan dan tutupan lahan. Sebagai contoh, kajian tentang perubahan tutupan lahan di bagian wilayah benua Afrika selama kurun waktu sepuluh tahun (Lambin dan Ehrlich, 1997); pantauan terhadap perubahan tutupan lahan di wilayah bagian Kota Bogota, Kolombia (Mendoza dan Etter, 2002); pendeteksian perubahan lahan dan tutupan lahan menggunakan citra satelit di Atlanta (Yang dan Lo, 2002); kajian terhadap perubahan guna lahan dan tutupan lahan di wilayah mediterania Turki (Kilic, et al., 2006); serta analisis terhadap perkembangan dan kesesuaian guna lahan di Kota Kahranmanmaras, Turki (Doygun, et al., 2008). Selain itu, penggunaan berbagai jenis data penginderaan jauh dan analisis Sistem Informasi Geografis (SIG) telah dilakukan untuk menganalisis perubahan lahan maupun tutupan lahan, diantaranya bisa dilihat dari hasil penelitian oleh Lambin dan Ehrlich (1997) yang menggunakan sepuluh tahun data NOAA-AVHRR; penggunaan data citra landsat TM oleh Yang and Lo, 2002; kajian evaluasi dan pemantauan perubahan guna lahan menggunakan SIG dan penginderaan jauh oleh Shalaby dan Tateishi (2007), dan Xiao, et al. (2006).

Berdasarkan penelitian tersebut, kemampuan analisis untuk memantau tingkat perubahan guna lahan atau tutupan lahan menjadi sesuatu yang penting bagi masyarakat pada umumnya, dan juga khususnya bagi para perencana dan penyusun kebijakan. Namun, kesulitan memperoleh data, informasi dan metode analisis kadangkala menjadi penghalang bagi para analis untuk mendeteksi perubahan guna lahan yang terjadi di wilayahnya. Seiring dengan meningkatnya akses terhadap data dan teknologi, ketersediaan dan kualitas data, serta metode analisis yang baru, maka saat ini dimungkinkan untuk melakukan pendeteksian guna lahan dengan singkat dan biaya yang tidak terlalu mahal.

Penelitian ini bertujuan untuk melakukan demonstrasi terhadap pendeteksian guna lahan dengan menggunakan data dan alat analisis yang mudah diakses. Citra Landsat dan analisis SIG digunakan untuk mendeteksi perubahan guna lahan di Wilayah Metropolitan Bandung (WMB), Indonesia pada tiga kurun waktu yaitu pada tahun 1979, 2006, dan 2014. Daerah perkotaan dipilih berdasarkan perubahan yang drastis akibat pengaruh urbanisasi dan pertumbuhan penduduk yang memberikan pengaruh signifikan terhadap kondisi lingkungan, ekonomi, dan kehidupan sosial perkotaan. WMB merupakan salah satu daerah perkotaan yang terdapat di Indonesia yang mengalami perkembangan perkotaan yang cukup pesat. Tingkat urbanisasi yang tinggi dan adanya proses perkotaan khususnya di daerah pinggiran telah memberikan dampak yang besar terhadap perubahan kondisi ekosistem perkotaan Bandung. Informasi terbaru dan akurat tentang kondisi dan kecenderungan perubahan ekosistem perkotaan, dalam studi ini yang dimaksud adalah perubahan guna lahan daerah perkotaan, diperlukan dalam rangka mengembangkan beberapa strategi pembangunan berkelanjutan dan peningkatan kehidupan perkotaan.

Artikel ini memuat enam bagian. Bagian pertama merupakan pendahuluan yang menguraikan latar belakang dan tujuan dari studi ini. Gambaran umum tentang wilayah studi di WMB diuraikan pada bagian kedua. Pada bagian ketiga, penjelasan singkat mengenai SIG dijabarkan pada bagian ini. Data dan metode 
yang digunakan pada studi ini diuraikan pada bagian keempat. Selanjutnya, hasil analisis dan pembahasan dari pendeteksian guna lahan di WMB dijelaskan pada bagian kelima. Artikel ini ditutup oleh kesimpulan pada bagian keenam.

\section{WILAYAH STUDI}

Wilayah studi pada penelitian ini adalah daerah perkotaan yang terdapat Wilayah Metropolitan Bandung (WMB). WMB berlokasi di Provinsi Jawa Barat, Indonesia (lihat Gambar 1). WMB dikenal juga dengan sebutan Bandung Raya. Secara administrasi WMB terdiri dari beberapa kota dan kabupaten, yaitu Kota Bandung, Kota Cimahi, Kabupaten Bandung, Kabupaten Bandung Barat, dan beberapa kecamatan di Kabupaten Sumedang. WMB merupakan wilayah metropolitan terbesar ketiga di Indonesia setelah wilayah metropolitan Jabodetabek dan Gerbangkertosusila.

Gambar 1. Lokasi Wilayah Studi (Google Map, 2014)

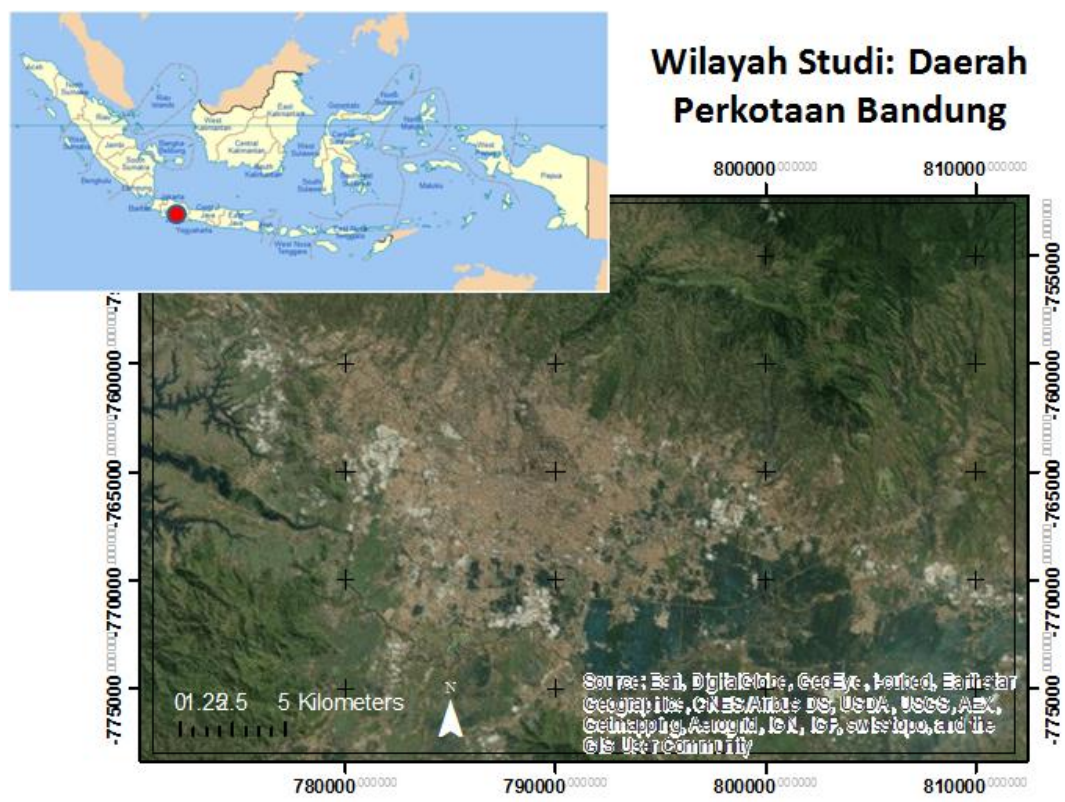

WMB memiliki luas 3.413,68 kilometer persegi dan jumlah penduduk hampir mencapai 8 juta jiwa. Kota Bandung memiliki kepadatan tertinggi yaitu sekitar 14.236 jiwa per kilometer persegi, kemudian diikuti oleh Kota Cimahi sebesar 13.135 jiwa per kilometer persegi. Luas wilayah, jumlah, dan kepadatan penduduk di WMB dapat dilihat pada Tabel 1.

Tabel 1. Luas, Jumlah, dan Kepadatan Penduduk di Wilayah Metropolitan Bandung (BPS, 2010)

\begin{tabular}{|c|c|c|c|}
\hline Kota/Kabupaten & $\begin{array}{l}\text { Luas } \\
\left(\mathrm{km}^{2}\right)\end{array}$ & $\begin{array}{l}\text { Penduduk } \\
\text { (jiwa) }\end{array}$ & $\begin{array}{l}\text { Kepadatan } \\
\left(\text { jiwa } / \mathrm{km}^{2} \text { ) }\right.\end{array}$ \\
\hline Kota Bandung & 168,23 & 2.394 .873 & 14.236 \\
\hline Kota Cimahi & 41,20 & 541.177 & 13.135 \\
\hline Kabupaten Bandung & $1.756,65$ & 3.178 .543 & 1.809 \\
\hline Kabupaten Bandung Barat & $1.335,60$ & 1.510 .284 & 1.131 \\
\hline $\begin{array}{l}\text { Kabupaten Sumedang (Kecamatan Tanjungsari, Kecamatan Cimanggung, } \\
\text { Kecamatan Jatinangor) }\end{array}$ & 112,00 & 264.342 & 2.360 \\
\hline Wilayah Metropolitan Bandung & $3.413,68$ & 7.889.219 & 2.311 \\
\hline
\end{tabular}

WMB dikelilingi oleh pegunungan dan perbukitan, sehingga bentuk morfologi wilayahnya seperti sebuah mangkok raksasa. Secara geografis, WMB berada di tengah-tengah dari Provinsi Jawa Barat, serta berada pada ketinggian kurang lebih 768 meter di atas permukaan laut (mdapl), dengan titik tertinggi di berada di 
bagian utara dengan ketinggian $1.050 \mathrm{mdpl}$, dan bagian selatan merupakan kawasan rendah dengan ketinggian 675 mdapl. Keadaan geologis dan tanah yang ada di WMB terbentuk pada zaman kuartier dan mempunyai lapisan tanah alluvial hasil letusan Gunung Tangkuban Parahu. Jenis material di bagian utara umumnya merupakan jenis andosol, begitu juga pada kawasan di bagian tengah dan barat, sedangkan kawasan di bagian selatan serta timur terdiri atas sebaran jenis alluvial kelabu dengan bahan endapan tanah liat. Sementara itu, iklim di WMB dipengaruhi oleh iklim pegunungan yang lembab dan sejuk, dengan suhu rata-rata 23,5 derajat Celcius, curah hujan rata-rata 200,4 milimeter, dan jumlah hari hujan rata-rata 21,3 hari per bulan.

Daerah WMB berdasarkan pewilayahan ekologis terdiri dari ekosistem hutan lindung, hutan budidaya, hutan campuran, lahan budidaya, dan permukiman. Selain itu, WMB berada pada beberapa sub daerah aliran sungai (DAS), yaitu sub DAS Cikapundung, sub DAS Cimanuk, sub DAS Ciwidey, sub DAS Cisangkuy, dan Sub DAS Citarum. Penurunan lahan hutan dan kualitas kondisi sungai di DAS telah terlihat secara drastis akibat intervensi manusia diantaranya yaitu pemotongan dan pembersihan hutan untuk perkebunan dan permukiman, serta pembangunan beberapa industri dan kawasan pemukiman di daerah pinggiran WMB.

Beberapa definisi Sistem Informasi Geografis (SIG) telah banyak dibahas oleh beberapa pihak diantaranya dapat terlihat pada Tabel 2. Walaupun demikian, secara umum SIG dapat diartikan secara ringkas yaitu suatu sistem yang berhubungan dengan informasi geografis. SIG banyak digunakan oleh beberapa pihak dari berbagai kalangan, khususnya yang terkait dengan bidang geografis dan teknologi komputasi. Sesuai perkembangannya, saat ini penggunaan SIG tidak hanya terbatas pada bidang geografis dan komputasi, tetapi sudah menjalar ke bidang lainnya (Maguire, 1991), diantaranya bidang pertanian, ekonomi, matematika, perencanaan tata ruang wilayah dan kota. Beberapa metode dan alat analisis telah diaplikasikan menggunakan SIG. Yang paling umum digunakan adalah aplikasi klasifikasi.

Tabel 2. Definisi Sistem Informasi Geografis (terjemahan dari Maguire, 1991)

\begin{tabular}{|c|c|}
\hline Uraian & Sumber \\
\hline $\begin{array}{l}\text { Suatu sistem yang berfungsi untuk pengambilan, penyimpanan, pemeriksaan, memanipulasi, } \\
\text { menganalisis, dan penampilan data yang bereferensi secara spasial terhadap Bumi. }\end{array}$ & DoE (1987:132) \\
\hline $\begin{array}{l}\text { Setiap rangkaian prosedur, baik yang berbasis manual ataupun komputasi yang digunakan untuk } \\
\text { menyimpan dan memanipulasi data yang bereferensi secara geografis. }\end{array}$ & Aronoff (1989:39) \\
\hline $\begin{array}{l}\text { Suatu bagian dari institusi, yang merefleksikan suatu struktur organisasi yang mengintegrasikan } \\
\text { teknologi dengan dukungan basis data, keahlian dan dana secara berkelanjutan sepanjang waktu. }\end{array}$ & Carter (1989:3) \\
\hline $\begin{array}{l}\text { Suatu informasi teknologi yang menyimpan, menganalisis, dan menampilkan data spasial dan non- } \\
\text { spasial }\end{array}$ & Parker (1988:1547) \\
\hline $\begin{array}{l}\text { Suatu sistem informasi yang secara khusus, dimana sumber data terdiri observasi fitur, kegiatan, atau } \\
\text { kejadian yang terdistribusi secara spasial, didefinisikan dalam ruang dalam bentuk titik, garis atau } \\
\text { daerah. SIG memanipulasi data tersebut yang berupa titik, garis, dan ruang dan kemudian } \\
\text { menampilkan data yang diolah tersebut kembali untuk suatu tujuan dan analisis yang diinginkan }\end{array}$ & Dueker (1979:106) \\
\hline $\begin{array}{l}\text { Suatu sistem basis data yang dimana hampir seluruh data terindeks secara spasial, selain itu juga } \\
\text { merupakan suatu rangkaian prosedur yang dioperasikan dalam rangka untuk menjawab pertanyaan } \\
\text { tentang aspek spasial dalam basis data }\end{array}$ & Smith, et al. (1987:13) \\
\hline $\begin{array}{l}\text { Suatu rangkaian fungsi otomatis yang menyediakan kemampuan dengan kapabilitas mutakhir untuk } \\
\text { penyimpanan, pengambilan kembali, memanipulasi, dan penampilan data lokasi secara geografis }\end{array}$ & $\begin{array}{l}\text { Ozemoy, Smith and } \\
\text { Sicherman (1981:92) }\end{array}$ \\
\hline $\begin{array}{l}\text { Suatu rangkaian alat yang ampuh untuk mengumpulkan, menyimpan, pengambilan kembali sesuai } \\
\text { kebutuhan, mengubah dan menampilkan data spasial dari dunia nyata }\end{array}$ & Burrough (1986:6) \\
\hline $\begin{array}{l}\text { Suatu sistem pendukung keputusan yang melibatkan integrasi data yang bereferensi spasial dalam } \\
\text { penanganan masalah }\end{array}$ & Cowen (1988:1554) \\
\hline Suatu sistem ampuh yang memiliki kemampuan pemodelan secara geografis & $\begin{array}{l}\text { Koshkariov, Tikunov } \\
\text { and Trofimov } \\
(1989: 259)\end{array}$ \\
\hline $\begin{array}{l}\text { Suatu bentuk Sistem Informasi Manajemen yang memperkenankan untuk penampilan peta dari } \\
\text { informasi umum }\end{array}$ & $\begin{array}{l}\text { Devine and Field } \\
(1986: 18)\end{array}$ \\
\hline
\end{tabular}

Data penginderaan jauh berupa citra satelit merupakan salah satu data yang sering digunakan dalam aplikasi SIG. Penggunaan penginderaan jauh menggunakan citra satelit ini telah dilakukan beberapa peneliti dalam studinya (sebagai contoh Lambin dan Ehrlich, 1997; Yang dan Lo, 2002; Shalaby dan Tateishi, 2007; 
Xiao, et al., 2006; Yuan, et al., 2005). Studi tersebut diantaranya untuk memantau perubahan guna lahan dan tutupan lahan. Walaupun demikian, aplikasi SIG tidak hanya berfungsi melakukan klasifikasi yang terbatas pada fungsi guna lahan atau tutupan lahan menggunakan data penginderaan jauh. Namun, studi tersebut dapat dikembangkan terhadap bidang yang lain, diantaranya studi hubungan kondisi iklim di daerah perkotaan dan perubahan guna lahan/tutupan lahan di Jakarta, Indonesia (Tursilowati, et al., 2012), kajian tentang kaitan perubahan guna lahan dan perubahan suhu (Hidayati, et al., 2014). Selain itu, penggunaan SIG juga sudah banyak digunakan untuk menentukan kesesuaian lahan, salah satunya dalam menentukan daerah konservasi berdasarkan beberapa kriteria (Wijaya, 2004). Dapat disimpulkan bahwa fungsi aplikasi SIG sangat beragam sesuai dengan kebutuhan pengguna.

\section{DATA DAN METODE}

Perubahan guna lahan daerah perkotaan di WMB teridentifikasi melalui data citra satelit Landsat, serta penggunaan SIG dalam menganalisis klasifikasi guna lahan. Data citra satelit yang digunakan dalam analisis studi ini bersumber dari laman United States Geological Survey (USGS) yaitu di http://earthexplorer.usgs.gov/ yang diunduh pada bulan November 2014. Data citra satelit dapat diakses dengan melakukan proses pendaftaran terlebih dahulu. Adapun citra satelit tersebut yaitu Landsat Multipectral Scanner (MSS) tahun 1979, Landsat Thematic Mapper (TM) tahun 2006, dan Landsat Operational Land Imager (OLI) tahun 2014. Peranti lunak ArcGIS 10.2.2 digunakan sebagai alat untuk melakukan analisis. Peranti lunak tersebut dapat diperoleh melalui laman ini (http://www.esri.com/software/arcgis/arcgis-for-desktop/free-trial). Walaupun hanya bisa digunakan sementara yaitu selama 60 hari, peranti lunak tersebut telah dilengkapi dengan beberapa tambahan alat analisis yang berguna dalam melakukan analisis klasifikasi tutupan lahan atau guna lahan yang berasal dari data citra satelit.

Berdasarkan literatur, beberapa metode telah digunakan untuk melakukan deteksi perubahan. Metode tersebut menghasilkan berbagai macam hasil karena dipengaruhi oleh karakteristik data citra udara, kondisi lingkungan fisik dan metode proses gambar (Berberoğlu and Akın, 2009). Pada perkembangannya, dalam upaya peningkatan akurasi dari klasifikasi tutupan lahan di daerah perkotaan, beberapa peneliti telah menggunakan beberapa pendekatan yang cukup rumit, diantaranya: (1) penggunaan neural networks (Berberoglu, et al., 2000; Kumar, et al., 1997; Paola and Schowengerdt, 1995); (2) klasifikasi fuzzy (Bastin, 1997; Fisher dan Pathirana, 1990); dan (3) analisis tekstur gambar (Berberoglu, et al., 2000; Gong and Howarth, 1990; Iron dan Petersen, 1981; Stuckens, et al., 2000). Studi ini lebih fokus pada penggunaan metode sederhana yaitu "maximum likelihood" yang terdapat pada peranti lunak ArcGIS. Metode klasifikasi "maximum likelihood" adalah salah satu metode klasifikasi yang sering digunakan dalam pencitraan udara, dimana setiap piksel dari 'maximum likelihood' diklasifikasi menjadi beberapa kelas yang dimaksud (Gambar 2).

Gambar 2. Alur Pemikiran Studi (Penulis, 2014)

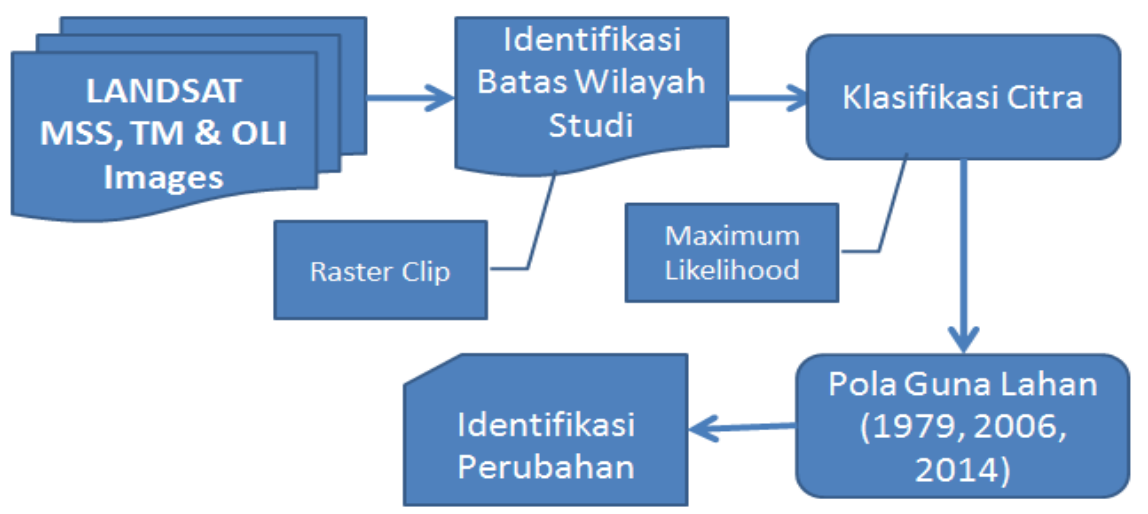

Menurut Danoedoro (1996), pada algoritma 'maximum likelihood' ini, piksel dikelompokkan dalam kelas sebagai objek tertentu menurut bentuk, ukuran, dan orientasi sampel pada ruang fitur yang berupa 
elipsoida. Informasi statistik berupa rerata dan simpangan baku tiap sampel, serta variansi dan kovariansi digunakan untuk menentukan klasifikasi. Ukuran elipsoida ditentukan oleh nilai variansi pada tiap saluran, sedangkan bentuk dan orientasi elipsoida ditentukan oleh kovariansinya. Informasi statistik tiap piksel tersebut kemudian dianalisis untuk masuk kelas tertentu.

Alur pemikiran dari studi ini dapat dilihat pada Gambar 2. Data citra satelit Landsat yang diperoleh dari sumber data USGS kemudian dilakukan identifikasi batas wilayah studi. Penentuan batas wilayah studi menggunakan alat analisis yang terdapat dalam peranti lunak ArcGIS yaitu "raster clip", yang membantu dalam memilih daerah studi berdasarkan kebutuhan pengguna. Proses ini dilakukan pada setiap citra satelit yang diperoleh. Hasil dari proses ini dapat dilihat pada Gambar 3, 4, dan 5. Selanjutnya, dilakukan proses klasifikasi citra satelit menggunakan alat analisis "maximum likelihood". Alat analisis ini terdapat dalam peranti lunak ArcGIS. Kemudian, hasil dari proses ini terbagi menjadi lima kelas klasifikasi guna lahan yang terdiri dari daerah perairan/waduk (water body/pond), permukiman (settlement), industri dan komersial (industrial/commercial area), hutan (forest), dan pertanian/perkebunan (agriculture). Untuk mereduksi distorsi, misalnya kumpulan awan, dan diragukan mengalami perubahan besar pada tutupan lahan maka dilakukan uji validasi sederhana.

Gambar 3. Daerah Perkotaan Bandung Tahun 1979 (Landsat MSS, 1979)

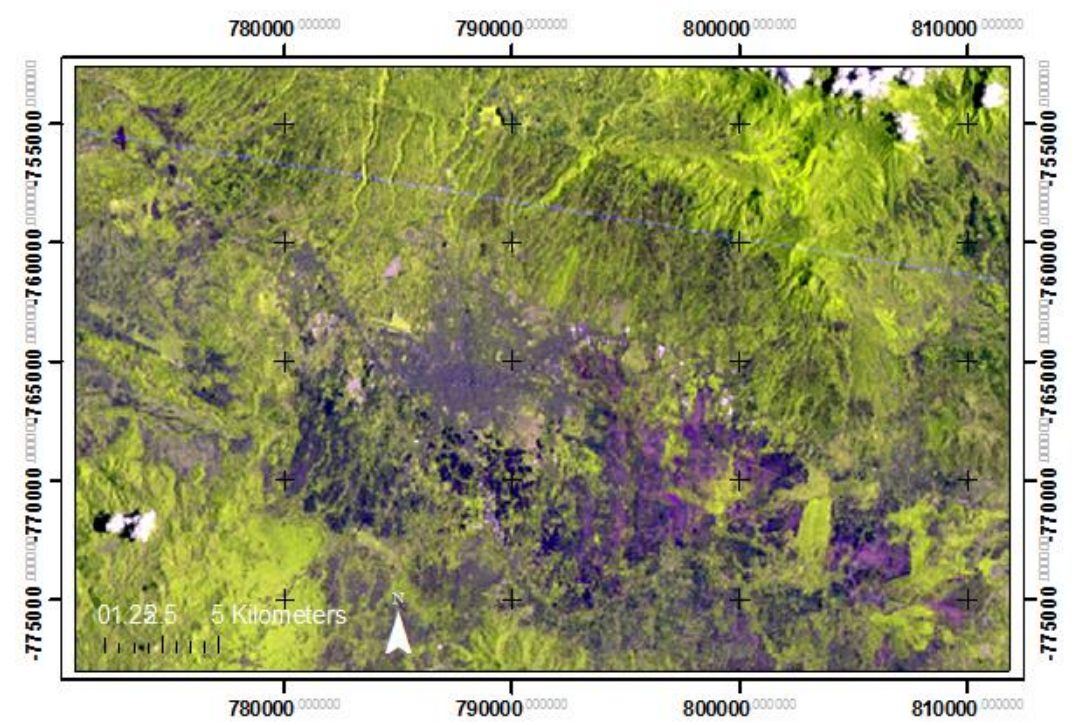

Hasil tampilan tiap data citra satelit menghasilkan hasil berbeda. Hal ini disebabkan karena pengaruh dari karakteristik setiap jenis data citra Landsat yang ada. Berdasarkan citra Landsat MSS tahun 1979 (Gambar 3), terlihat bahwa, wilayah studi masih didominasi oleh lahan yang tidak terbangun.

Gambar 4. Daerah Perkotaan Bandung Tahun 2006 (Landsat TM, 2006)

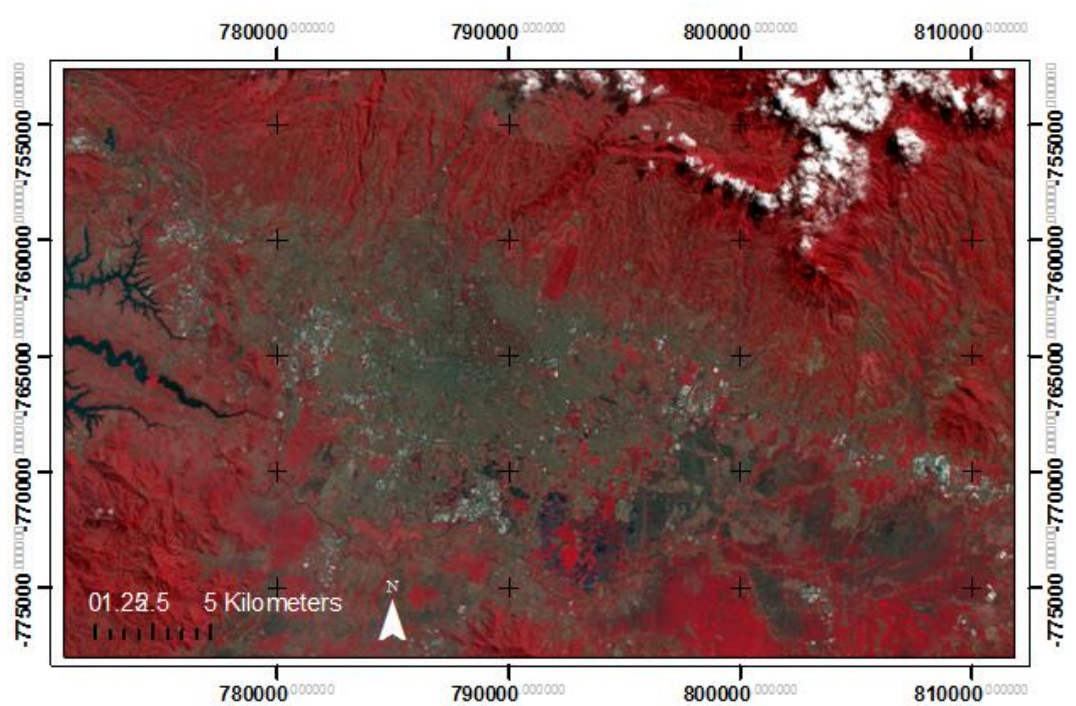


Data citra satelit Landsat TM tahun 2006 di wilayah studi (Gambar 4) terdapat distorsi kumpulan awan di bagian timur laut. Hal ini merupakan salah satu tantangan dalam memperoleh data satelit dari hasil penginderaan jauh. Oleh karena itu, dalam pencarian data dibutuhkan kesabaran dan ketelitian, karena data yang diperoleh tidak sepenuhnya sempurna. Hal yang perlu diperhatikan adalah kualitas data, dimana itu akan menentukan hasil analisis. Semakin baik kualitas data, maka semakin baik pula hasil analisis yang diperoleh. Adapun data citra satelit Landsat OLI pada tahun 2014 dapat dilihat pada Gambar 5.

Gambar 5. Daerah Perkotaan Bandung Tahun 2014 (Landsat OLI, 2014)

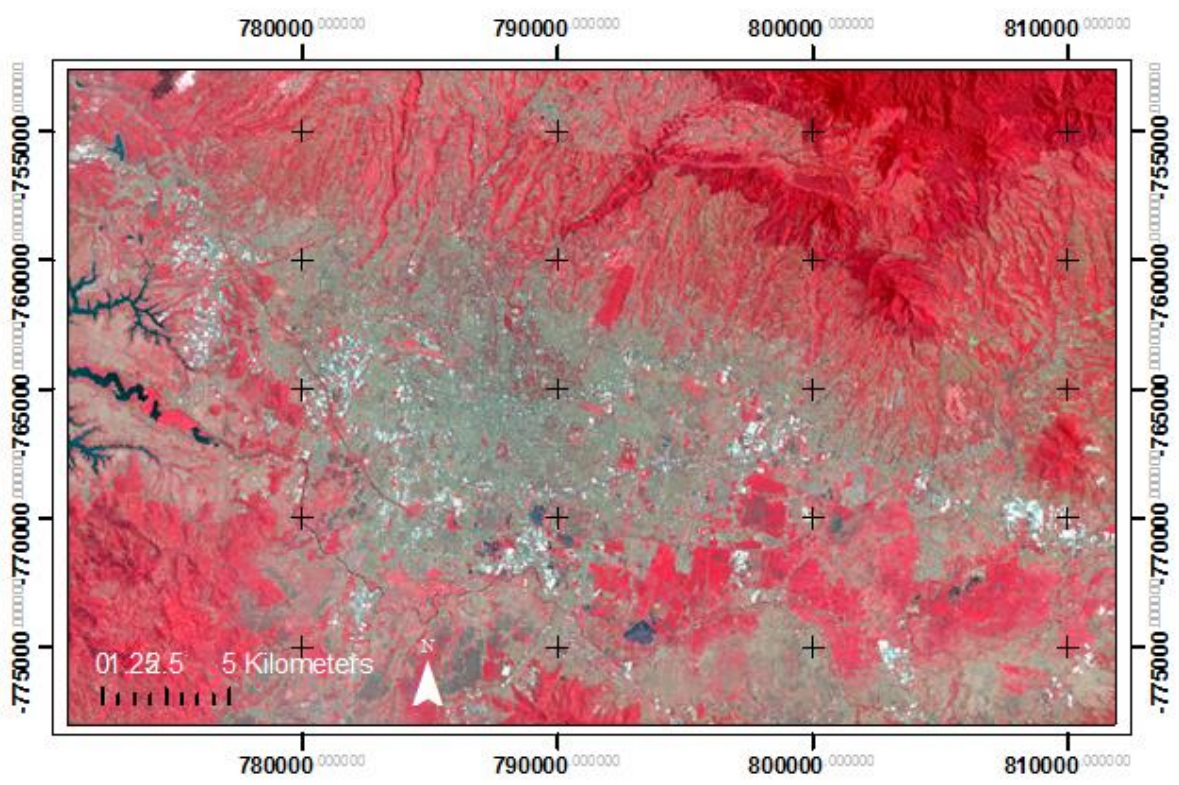

Untuk meminimalisasi distorsi, misalnya tutupan awan, dan keraguan terhadap perubahan yang drastis pada citra satelit yang diperoleh, maka dilakukan uji validasi sederhana dengan melakukan evaluasi pola tanggapan spektral setiap kategori tutupan lahan. Uji tersebut yang digunakan dalam penelitian ini yaitu pengukuran atau evaluasi daya pisah spektral dengan menggunakan matriks kesalahan dimana penyimpangan klasifikasi berupa kelebihan jumlah piksel dari kelas lain atau kekurangan jumlah piksel yang masuk ke kelas lain.

\section{HASIL DAN PEMBAHASAN}

Proses perubahan guna lahan di Wilayah Metropolitan Bandung terjadi akibat adanya urbanisasi dan pertumbuhan penduduk yang meningkat. Deteksi perubahan guna lahan daerah perkotaan dikaji dengan bantuan data penginderaan jauh berupa citra satelit Landsat dan SIG (Xiao et al., 2006). Dalam rangka untuk membantu mendeteksi perubahan guna lahan, dalam proses analisis pada tiap hasil klasifikasi guna lahan digunakan alat analisis berupa radius (buffer) yang terbagi menjadi tiga lingkaran radius yang berbeda (lihat Gambar 6, Gambar 7, dan Gambar 8). Lingkaran pertama diasumsikan sebagai pusat inti kota (city core). Pusat inti kota merupakan pusat kegiatan dari suatu kota, dimana pada umumnya terdiri dari pusat pemerintahan, pusat sosial dan budaya, serta pusat perdagangan dan jasa. Lingkaran kedua merupakan kawasan perkotaan (inner city) dan lingkaran ketiga sebagai daerah pinggiran kota (sub-urban/outer city).

Kawasan perkotaan kecenderungan memiliki tingkat kepadatan penduduk yang lebih tinggi dibandingkan daerah pinggiran kota (Yuan et al., 2005). Berdasarkan hasil analisis, terlihat bahwa kawasan terbangun di WMB terjadi peningkatan yang cukup signifikan. Perkembangan daerah perkotaan awalnya hanya berada di pusat inti kota dan sebagian terdapat di kawasan perkotaan. Namun, seiring bertambahnya waktu, perkembangannya meningkat hingga kawasan pinggiran kota. Peningkatan daerah perkotaan yang drastis di WMB dibuktikan dengan adanya pembangunan yang terjadi secara terus menerus di wilayah perkotaan, diantaranya yang dapat teridentifikasi yaitu proses migrasi dari perdesaan menuju daerah perkotaan, dan kebijakan pemerintah terkait dengan pembangunan untuk investasi industri, perumahan dan infrastruktur. 
Gambar 6. Klasifikasi Guna Lahan Perkotaan Bandung Tahun 1979 (hasil analisis, 2014)

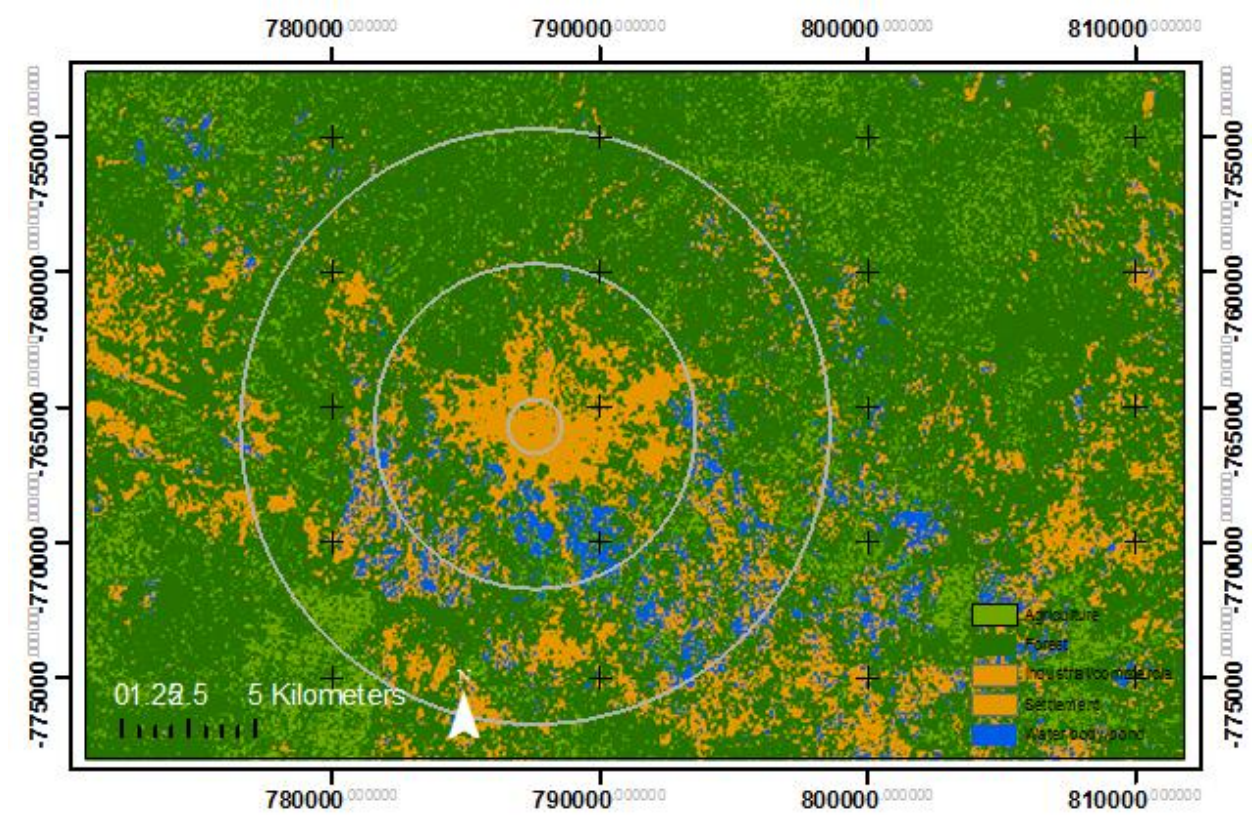

Kondisi guna lahan WMB pada tahun 1979 dapat terlihat pada Gambar 6. Kondisi lahan tidak terbangun masih mendominasi dibandingkan kawasan terbangun. Besaran luasan kawasan terbangun masih berada dalam lingkup wilayah pusat inti kota dan kawasan perkotaan. Hal ini menandakan bahwa lahan fungsi hutan masih dominan dan terlihat kawasan perairan atau danau masih terlihat jelas.

Gambar 7. Klasifikasi Guna Lahan Perkotaan Bandung Tahun 2006 (hasil analisis, 2014)

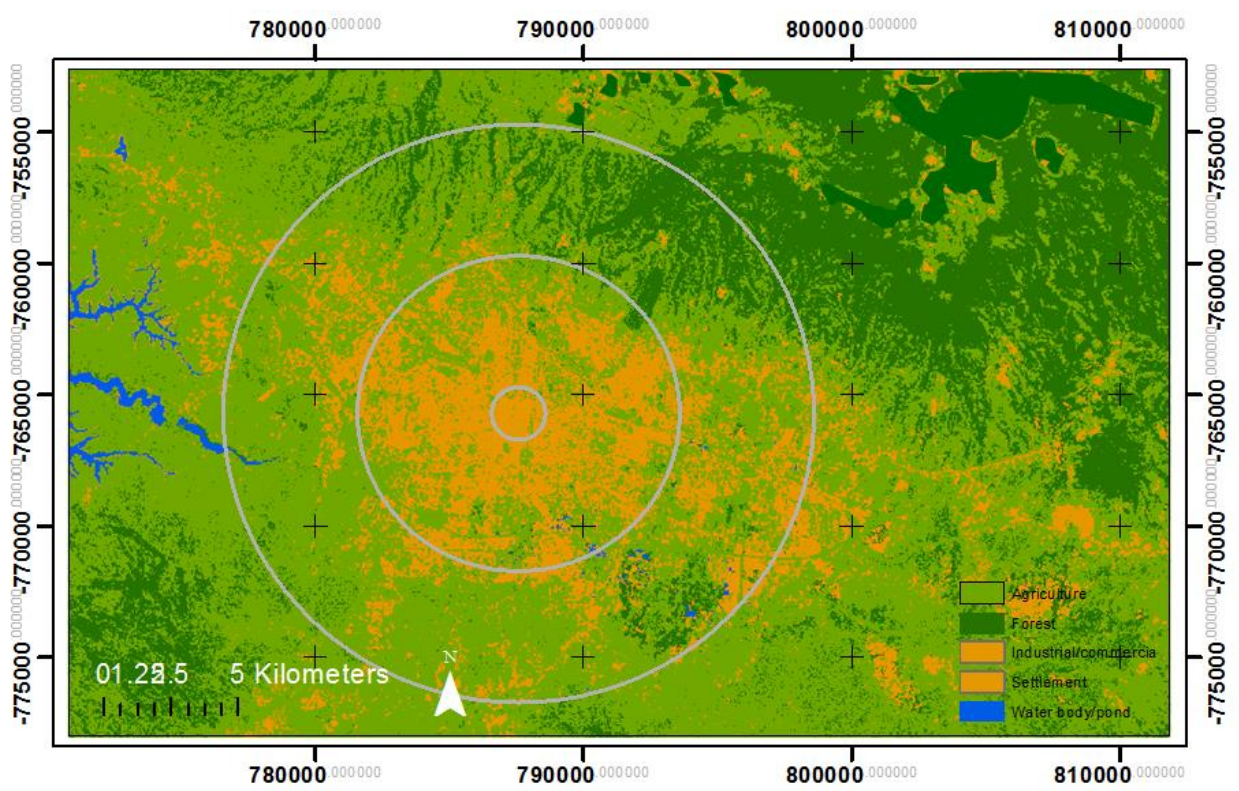

Pada tahun 2006, ekspansi penduduk terlihat mulai berkembang ke arah timur, selatan dan barat. Bagian utara dibatasi oleh kawasan lindung berupa hutan, sehingga perkembangan terbatas hanya di bagian tertentu. Pada periode ini, terjadi peningkatan penduduk akibat urbanisasi. Akses transportasi jalan telah memebntuk perkembangan pola permukiman sepanjang jalan. Adanya jalan tol Cipularang yang menghubungkan wilayah metropolitan Bandung dan Jabodetabek juga telah mempengaruhi perkembangan perkotaan di WMB. Lingkaran kedua yang merupakan kawasan perkotaan sudah terisi penuh, apabila dibandingkan dengan kondisi yang terjadi pada tahun 1979. Hal ini mengindikasikan, bahwa di WMB telah terjadi perkembangan daerah perkotaan dan perubahan guna lahan yang cukup signifikan. 
Gambar 8. Klasifikasi Guna Lahan Perkotaan Bandung Tahun 2014 (hasil analisis, 2014)

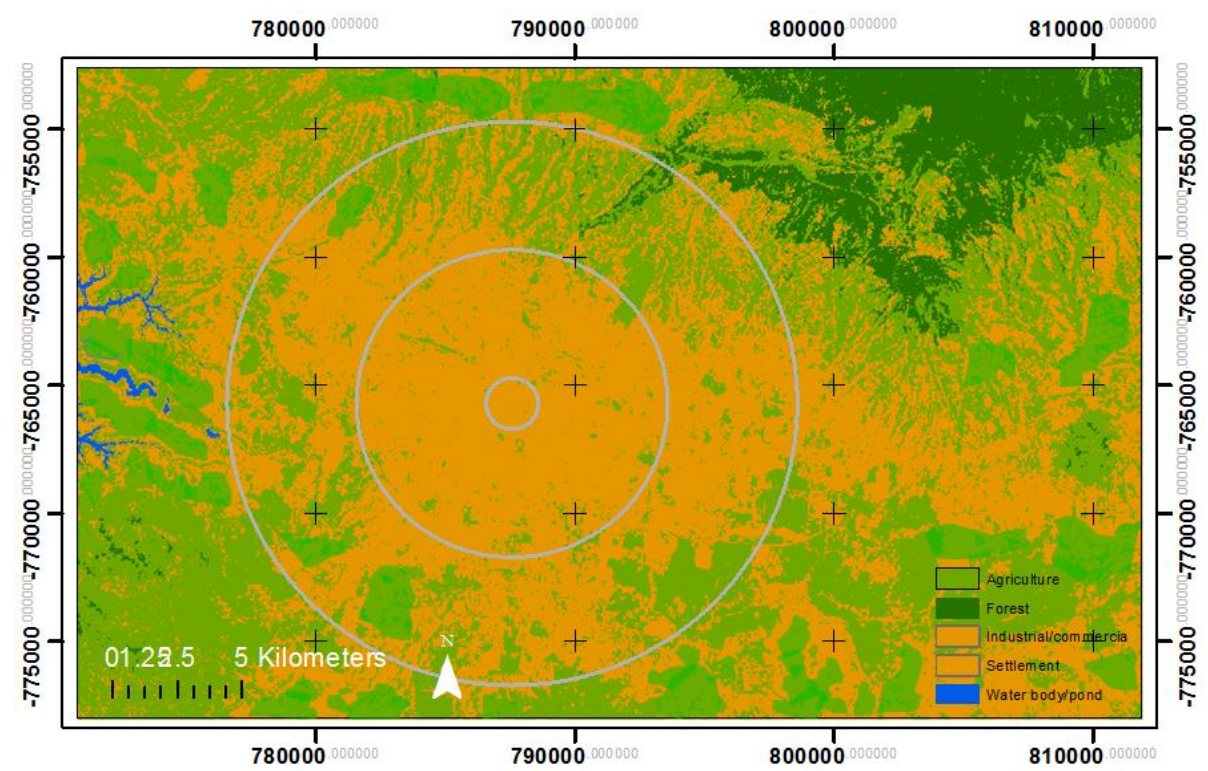

Pada tahun 2014, peningkatan daerah perkotaan di WMB terjadi peningkatan secara drastis. Hal ini dapat dilihat pada Gambar 8. Perkembangan daerah perkotaan mulai merambah ke kawasan hutan yang terdapat di bagian utara. Selain itu, semakin banyak kawasan permukiman di bagian pinggiran kota. Perubahan guna lahan terlihat didominasi oleh kawasan terbangun dibandingkan kawasan non-terbangun. Kondisi pada tahun 2014 berbeda sangat mencolok dengan kondisi yang terjadi pada tahun 1979.

Gambar 9. Perubahan Guna Lahan Perkotaan Bandung Tahun 1979, 2006, dan 2014 (Hasil analisis, 2014)

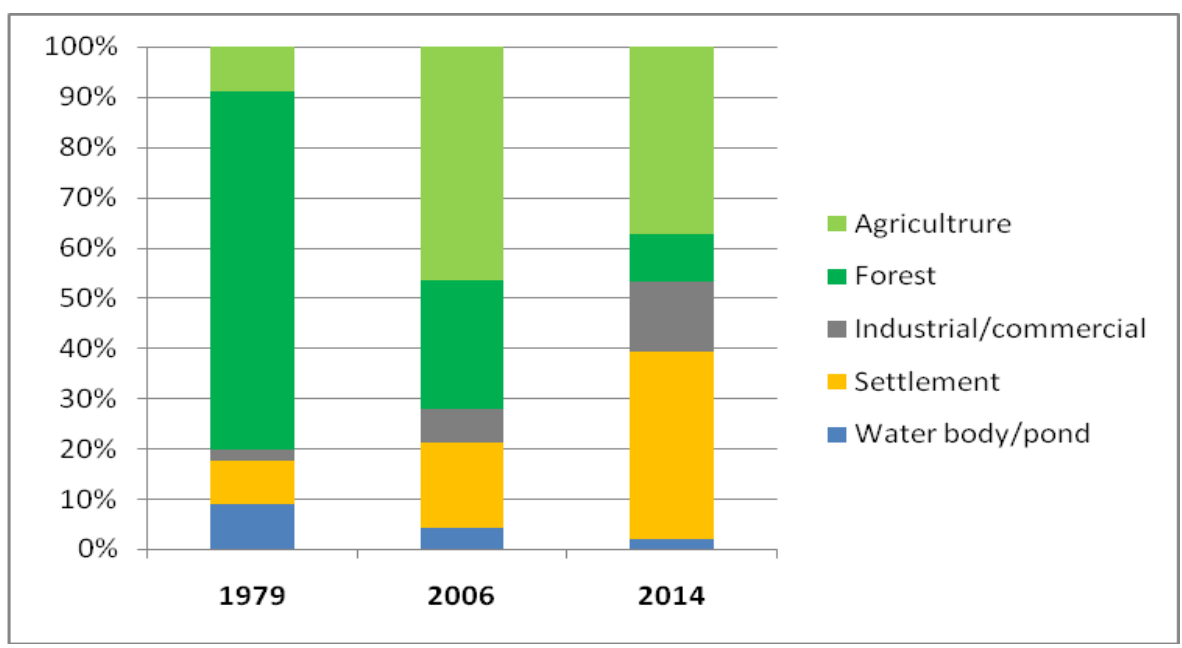

Berdasarkan hasil yang diperoleh dari deteksi perubahan guna lahan daerah perkotaan di WMB, ekspansi daerah perkotaan telah terjadi peningkatan. Pemanfaatan lahan permukiman semakin meningkat, sedangkan peruntukan lahan hutan semakin berkurang (lihat Gambar 9). Hal menarik adalah adanya peningkatan peruntukan lahan industri dan komersial. Ini mengindikasikan bahwa telah terjadi perubahan alih fungsi lahan dari yang tidak terbangun menjadi lahan terbangun, serta pemekaran daerah perkotaan ke daerah sekitarnya. Sesuai dengan Evrendilek dan Doygun (2000), hasil Ini memberikan tantangan yang cukup signifikan bagi pengembangan WMB khususnya dalam usaha untuk mencapai pembangunan perkotaan yang berkelanjutan. 


\section{KESIMPULAN}

Pada umumnya, data dan informasi bahkan alat analisis untuk melakukan deteksi perubahan guna lahan kadangkala sulit untuk dilakukan. Hal ini dapat disebabkan oleh sulitnya mengakses data dan informasi yang akan digunakan bahkan memerlukan biaya yang tidak murah. Selain itu, alat analisis yang digunakan pun tidak mudah untuk diakses. Penelitian ini berusaha untuk memberikan demonstrasi secara sederhana terkait aplikasi SIG dengan menggunakan data penginderaan jauh berupa citra Landsat yang mudah diakses dalam rangka pendeteksian perubahan guna lahan daerah perkotaan di Wilayah Metropolitan Bandung selama tiga periode yaitu tahun 1979, 2006, dan 2014. Berdasarkan temuan yang diperoleh, sebenarnya terdapat beberapa data dan informasi serta alat analisis yang mudah diakses. Walaupun kualitas dan hasil analisis masih terbatas, namun hasil yang diperoleh memungkinkan untuk dijadikan acuan bagi para peneliti bahkan perencana serta penentu kebijakan dalam melihat perubahan guna lahan secara umum, misalnya perubahan guna lahan berdasarkan klasifikasi tutupan lahan dan kecenderungan ekspansi.

Pemantauan ekspansi daerah perkotaan menggunakan data citra satelit dan SIG merupakan suatu hal yang penting dalam kaitannya dengan perencanaan tata ruang dan lingkungan. Penggunaan citra satelit yang memiliki resolusi yang tinggi memungkinkan untuk memantau perubahan guna lahan secara rinci. Studi ini menggambarkan daerah perkotaan di WMB telah terjadi perkembangan secara signifikan selama tiga periode waktu, dikarenakan oleh tingkat urbanisasi dan pertumbuhan populasi yang pesat di daerah tersebut. Identifikasi perkembangan daerah perkotaan perlu diintegrasikan dengan proses ekologis dan ekonomi dalam rangka suksesnya pengelolaan yang berkelanjutan. Hal yang perlu diperhatikan adalah konsep pembangunan berkelanjutan dan penyediaan keseimbangan ekologis dan ekonomi terhadap perubahan guna lahan. Para perencana dan pembuat kebijakan memiliki peran penting dalam usaha mempertahankan daerah perkotaan tetap berkembang secara berkelanjutan.

Beberapa hal yang perlu dilakukan dalam rangka peningkatan hasil studi dan kemungkinan studi lebih lanjut, diantaranya yaitu perlunya melakukan proses validasi dan koreksi data, baik melalui data observasi lapangan maupun data dari sumber lain; pendeteksian dengan menggunakan data citra satelit yang memiliki resolusi yang tinggi dan metode analisis klasifikasi yang lebih baik; identifikasi faktor yang mempengaruhi perubahan guna lahan, misalnya pertumbuhan jumlah penduduk, harga lahan, kondisi ekonomi, kondisi infrastruktur, dan perubahan kondisi sosial. Secara keseluruhan, studi ini memperlihatkan bahwa aplikasi SIG telah membantu proses analisis untuk mendeteksi perubahan guna lahan yang terjadi di Wilayah Metropolitan Bandung. Selain itu, kemudahan akses terhadap data berupa data penginderaan jauh dan metode analisis memberikan alternatif terhadap para analis untuk terus tetap mengembangkan penggunaan aplikasi SIG dalam studinya terutama yang terkait dengan data geografis di masa mendatang.

\section{DAFTAR PUSTAKA}

Aronoff, S. (1989). Geographic Information Systems: A Management Perspective. Ottawa, Canada: WDL Publications.

Bastin, L. (1997). Comparison of fuzzy c-means classification, linear mixture modeling and MLC probabilities as tools for unmixing coarse pixels. International Journal of Remote Sensing, 18, 3629-3648.

Berberoğlu, S, \& Akın, A. (2009). Assessing different remote sensing techniques to detect land use/cover changes in the eastern Mediterranean. International Journal of Applied Earth Observation and Geoinformation, 11, 46-53.

Berberoğlu, S., et al. (2000). The integration of spectral and textural information using neural networks for land cover mapping in the Mediterranean. Computers and Geosciences, 26: 385-396.

Biro Pusat Statistik. (2010). Sensus Penduduk di Jawa Barat Tahun 2010. Jawa Barat, Indonesia: BPS. http://jabar.bps.go.id.

Danoedoro, P. (1996). Pengolahan Citra Digital; Teori dan Aplikasinya. Yogyakarta: Fakultas Geografi Universitas Gadjah Mada.

Doygun, H., Alphan H., \& Kuşat, G. D. (2008). Analysing urban expansion and land use suitability for the city of Kahramanmaraş, Turkey, and its surrounding region. Environment Monitoring Assessment, Vol 145: 387-395. 
Evrendilek, F., \& Doygun, H. (2000). Assessing major ecosystem types and the challenge of sustainability in Turkey. Environmental Management, 26(5), 479-489.

Fisher, P. F., \& Pathirana, S. (1990). The evaluation of fuzzy membership of land cover classes in the suburban zone. Remote Sensing of Environment, Vol. 34: 121-132.

Gong, P., \& Howarth, P. J. (1990). The use of structural information for improving land cover classification accuracies at the rural-urban fringe. Photogrammetric Engineering and Remote Sensing, 56(1): 6773.

Hidayati, I., et al. (2014). Analysis of Image Transformation and Land Use/Land Cover for Temperature Trends on Landsat Imagery. Thematic Cartography For The Society, 275-291.

Iron, J. R., \& Petersen, G. W. (1981). Texture transforms of remote sensing data. Remote Sensing of Environment, 11, 359-370.

Kilic, S., et al. (2006). Environmental Monitoring of Land-Use and Land-Cover Changes in a Mediterranean Region of Turkey. Environmental Monitoring and Assessment, 114, 157-168.

Kumar, A. S., Basu, S. K., \& Majumdar, K. L. (1997). Robust classification of multispectral data using multiple neural networks and fuzzy integral. IEEE Transactions on Geoscience and Remote Sensing, vol 35: 787-790.

Lambin, E. F., \& Ehrlich, D. (1997). Land-cover changes in Sub-Saharan Africa (1982-1991): Application of a change index based on remotely sensed surface temperature and vegetation indices at a continental scale. Remote Sensing Environment, 61(2): 181-200.

Maguire, D. J. (1991). An overview and definition of GIS. Geographical information systems: Principles and applications, 1, 9-20.

Mendoza, J. E., \& Etter, R. (2002). Multitemporal analysis (1940-1996) of land cover changes in the southwestern Bogota highplain (Colombia). Landscape and Urban Planning, 59(3): 147-158.

Paola, J. D., \& Schowengerdt, R. A. (1995). A detailed comparison of back propagation neural networks and maximum likelihood classifiers for urban land use classification. IEEE Transactions on Geoscience and Remote Sensing, 33, 981-996.

Shalaby, A., \& Tateishi, R. (2007). Remote sensing and GIS for mapping and monitoring land cover and landuse changes in the Northwestern coastal zone of Egypt. Applied Geography, 27(1): 28-41.

Stuckens, J., Coppin, P. R., \& Bauer, M. E. (2000). Integrating contextual information with per pixel classification for improved land cover classification. Remote Sensing of Environment, 71, 282-296.

Tursilowati, L., Sumantyo, J. T. S., Kuze, H., \& Adiningsih, E. S. (2012). Relationship between urban heat island phenomenon and land use/land cover changes in Jakarta - Indonesia. Journal of Emerging Trends in Engineering and Applied Sciences, 3(4): 645-653.

Wijaya, N. (2004). Penggunaan GIS Dalam Menentukan Kawasan Konservasi, Studi Kasus: Kawasan Bandung Utara. Makalah dipresentasikan pada Seminar Nasional "Perencanaan Wilayah dan Kota dalam Perubahan Multidimensi" dalam rangka memperingati 45 Tahun Pendidikan Planologi ITB. Jurusan Teknik Planologi ITB, Bandung.

Xiao, J., et al. (2006). Evaluating urban expansion and land use change in Shijiazhuang, China, by using GIS and remote sensing. Landscape and urban planning, 75(1): 69-80.

Yang, X., \& Lo, C. (2002). Using a time series of satellite imagery to detect land use and land cover changes in the Atlanta, Georgia metropolitan area. International Journal of Remote Sensing, 23(9), 1775-1798.

Yuan, F., et al. (2005). Land cover classification and change analysis of the Twin Cities (Minnesota) Metropolitan Area by multitemporal Landsat remote sensing. Remote Sensing of Environment, 98(2), 317-328. 